\title{
AN OVERVIEW OF GERMAN CENTERS OF CORPORATE DOMINANCE AND MOTIVES FOR CORPORATE HEADQUARTERS RELOCATION
}

\section{Tyll, L., Srivastava, M., Březina, F.}

The purpose of this paper is to identify the centers of corporate dominance in Germany, and the main drivers of recent headquarter relocations within the country. The analysis is based on a literature review, a database comprising the 10,000 most significant companies in Germany and additional research for qualitative input to support the interpretation of the findings. The findings show that corporate dominance in Germany is decentralized. Centers with relative corporate dominance tend to host a higher proportion of public limited companies. These public limited companies had a turnover of over one billion Euros, and most of these companies were founded after the year 2000. The main drivers for recent $\mathrm{HQ}$ relocations were corporate restructuring (mergers and demergers) and the centralization of functions. Furthermore, it has been found that differences in the trade tax burden between municipalities have had no influence on recent relocation decisions within Germany.

Keywords: Germany, centers of corporate dominance, headquarter relocation, $\mathrm{HQ}$ relocation drivers

JEL Classification: M30, M31

\section{Introduction}

Corporate headquarters are the brains of large corporations. Headquarters (HQ) are the place where central functions are performed and where the board of management takes strategic decisions often affecting hundreds of thousands of employees and stakeholders. Corporate headquarters are of integral importance to companies and decision makers will carefully consider where to locate them. On the other hand, cities and municipalities are eager to attract corporate headquarters to their areas to benefit from the high-paid jobs headquarters create. Moreover, depending on the country, a portion of the corporate or trade tax collected from these companies might contribute to the local treasury's annual budget. 
This interplay of careful planning on behalf of the company and the competition between cities to host headquarters is well illustrated by Amazon's announcement to build HQ2 - a second location for its corporate headquarters. The company's main HQ is located in Seattle, a city to which Amazon's investment is estimated to have added 38 billion USD to the economy between 2010 and 2016 (Wharton, 2017). The company created a public tender and asked cities to compete for the opportunity of hosting the second Amazon headquarters. In response, numerous cities applied and among 20 serious contestants, Northern Virginia and New York City were eventually chosen to host HQ2 and HQ3 (Stevens \& Morris, 2018).

The extent to which Amazon's search process received attention elevated the question of how critical corporate headquarters can be, for both the company and the host city as well as to the public sphere. There has been extensive research about centers of corporate dominance and reasons for HQ relocations in the United States. The European context is often not touched upon or used only comparatively to the situation in the US. The case in continental Europe has received little attention from researchers, and it is, therefore, the objective of this paper to put this topic in the context of Germany by analyzing the largest 10,000 German companies. Many important questions such as where the centers of corporate dominance in Germany are located? Do these centers share certain characteristics? What are the reasons for which German companies decide to relocate their corporate headquarters? We attempted to answer these questions to understand the similarities and potential differences between the situation in Germany and existing research about the United States. The findings shall prove to be relevant for all those seeking to understand how corporate power is distributed within Germany and for those who seek to understand what drove the recent relocations of large corporations' headquarters. The latter is particularly interesting because of the high cost and planning efforts involved in relocating the HQ of one of the largest companies in Europe's strongest economy which represents an important business partner for Central and Eastern European countries (Machek, 2012).

In this paper, we attempted to give an overview of where corporate power can be found within Germany based on a database adapted from Bureau van Dijk (2018) comprising information about Germany's largest 10,000 companies (according to total turnover). Furthermore, HQ relocations of the 100 largest German companies within the last ten years were analyzed in an attempt to provide an understanding of the motives and main drivers for these relocations.

\section{Literature Review}

\subsection{Corporate headquarters and their strategic importance}

Boyle (1988) defines corporate headquarters as a facility in which a company's chief executive and key associates have their primary offices. Porter's (1996) explained corporate headquarter as a corporate home base where strategy is set, core product and process development takes place, and where the essential and proprietary skills reside (Porter, 1996; Rao, 2015). However, there exist more narrow definitions such as the restriction to the term 
to the physical corporate center as part of the home base of the corporate parent (Rao, 2015). Moreover, a distinction can also make between headquarters of multi-site firms (business establishments with branches or divisions) and single-site firms, which locate both production and headquarter activity at the same location (Strauss-Kahn \& Vives, 2006).

According to Boyle (1988), the larger the corporation, the more elaborate the administrative support structure. Rao (2015) argues that the globalization of production processes, R\&D and corporate functions lead to a concentration of the latter. In comparison to European headquarters, US headquarters are twice the size on average, and Japanese headquarters are more extensive than anywhere else. Collis et al. (2007) found a positive correlation between companies and headquarter size (measured by the number of employees in both cases) in their survey of 600 corporations in seven countries in the four corporate governance systems: Anglo-American, Continental European, Asian and developing countries.

The difference in roles of corporate headquarters between the United States, Japan, and the European countries was summarized by Rao (2015) using the key findings of Collis et al. (2008). It can be observed that Japanese companies tend to centralize corporate functions to a more significant extent than their counterparts in the United States and Europe continent. Japanese headquarters are also larger (regarding the number of employees working at the HQ) than their US and European counterparts (Collis et al., 2007). While it can be concluded that European companies are less centralized in their discretionary functions, not all the European countries in the analysis exhibit similar values. An outlier within the European countries is Germany. The relative number of headquarters staff (about overall staff) controlled for corporate portfolio, structure, ownership, and regulation in Germany amounts to 0.68 while for France, the Netherlands and the United Kingdom exhibit values between 0.32 and 0.4 (Rao, 2015).

Corporate headquarters are not only of strategic importance to the corporation itself, but they are also of considerable significance to the host communities. Corporate headquarters contribute to a region's economic standing by employing a high proportion of high-skilled labor in managerial and skilled technical functions (Boyle, 1988). The communities and their economic environment are often the very reason why corporations are founded there in the first place. As Holloway \& Wheeler (1991) point out, the largest US firms had traditionally been in metropolitan areas. Rao (2015) argues that the economic benefits of headquarters to the host economy are based on the fact that they generate a large number of highly skilled and high paid services jobs. Clausing (2010) distinguishes between the level of job (and investment) and the type of employment (and investment) and found out that multinational firm headquarters undertake activities that are likely to generate learning and innovation, since research, development and entrepreneurial activities are typically part of those activities performed primarily at the corporate headquarters. 
Germany has long been the most powerful industrial nation in continental Western Europe. In 1975, more industrial corporations were located in the country than in any other European nation. The majority of metropolitan regions have maintained their relative position of corporate influence (Strickland and Aiken, 1984). While in the United States, the centers of corporate dominance are located in large cities and regional "capitals" (even if they are often not the actual capitals of their respective states), European countries have traditionally had corporate dominant centers in and around their capitals. In 1965, 89 percent of the largest firms were in the Paris region and the early 1970s, 65 percent of the largest 500 firms in the United Kingdom were located in London (Strickland \& Aiken, 1984). However, this may be true for many European countries; Germany constitutes an exception in this regard as Germany is a country of many centers (Guertler, 2010).

Today's German center of political power is located in the East: Berlin is the German center of political influence, lobbying and related corporate activities. However, out of the 30 companies listed in the German stock index DAX (Deutscher Aktienindex), not a single one has its corporate headquarters exclusively in Berlin. As a matter of fact, Siemens is the only DAX company which located one of its two headquarters in the German capital, the second HQ location is in Munich (Deutsche Boerse, 2018). This leaves 29 DAX headquarters to the rest of Germany and even there, the locations are scattered across the nation. Next to wellknown centers of corporate dominance such as Frankfurt am Main (the location of Germany's stock exchange), Cologne, and Munich, there are some relics from the industrial age and several locations that do not necessarily correspond to Wheeler's (1988) findings concerning the correlation between population size and number of headquarters in a region in the United States. In other regards, however, the United States and its decentralized centers of corporate dominance show some similarities with the situation in the Federal Republic of Germany in the post-war period. The decentralized nature of political systems in both countries seems to cause the centers of corporate dominance to be more decentralized than in European countries other than Germany (Strickland \& Aiken, 1984).

The decentralized corporate dominance in Germany can be observed still today when looking at DAX companies and their headquarters. Some of the largest companies have their headquarters in more rural areas: Adidas, ranked first in the DAX, has its corporate headquarters in the Bavarian, a 23 thousand-inhabitant city of Herzogenaurach. Fresenius located its HQ in Bad Homburg vor der Hoehe, a city of barely over 50 thousand inhabitants. Similarly, the DAX companies Infenion, Frensenius Medical Care and Wirecard all located their corporate headquarters in cities with fewer than 50 thousand inhabitants (Deutsche Boerse, 2018).

\subsection{Corporate headquarters relocation}

Corporate headquarter relocation is a rare, and in the case of large publically traded companies, a costly phenomenon often accompanied by extensive media coverage. Therefore, the triggers for such an important decision have been of interest to a number of researchers. When researching corporate headquarters' moves, a distinction must be made 
between in-country and trans-border relocations. Similarly, the size of the company is an important factor which must not be forgotten in the analysis. Ye et al. (2011) found three main reasons relocation: Enterprises who depend highly on local political resources would find it difficult to decide to relocate their headquarters; Enterprises with high political resources optimization would be likely to relocate their headquarters driven by the pursuit of political resources; Enterprises with a strong political resources relevance in their business model would rather relocate their headquarters than be reclusive in central cities.

Apart from political resources, there are also internal and economic factors that play into the decision on whether and where to relocate. Rao (2015) argues that the most common triggering events for the relocation of corporate headquarters or functions thereof are: Startups; Expansions; Mergers and acquisitions; Outgrowing the current location; External business factors; Outcomes of mergers and acquisitions; Location of the initial start-up; Location of major owners; Collocation with a company's major operational facilities. In addition to the above list, Rao (2015) found out that the location of top executives and influential shareholders might also be of importance in the search for a (new) location for the company's corporate headquarters.

While triggers and major factors offer an idea of why a company chooses a certain location for their corporate headquarters, the list of factors which have an influence on the decision is much more extensive. Rao (2015) categorizes them into three channels: cost minimization, profit maximization and the quality of life for executives and professionals. However, there is no evidence that long-term performance improves after a relocation for the same reason. A more comprehensive list of 35 location factors for headquarters was offered by Burress (2006).

While in the United States, the subject of intra-country relocation of corporate headquarters is a well-studied issue, the issue of international relocation seems to be less of a focal point for researchers. In other countries, researchers seem to be more concerned with the threat of losing strategic importance for corporate headquarters because of globalization. Rao (2015) studied the development of corporate headquarter relocation in Canada. Although globalization of processes, often driven by mergers and acquisitions, could pose a threat to areas that traditionally host numerous corporate headquarters in industries affected by the globalization of the value chain, Canada seems to not have lost its strategic importance as a host of corporate headquarters in a significant way. Furthermore, headquarter activity is highly concentrated in large metropolitan areas in Canada, as well. The seven cities OttawaGatineau, Winnipeg, Edmonton, Calgary, Vancouver, Montreal and Toronto account for $82 \%$ of all headquarter activity and $57 \%$ of all headquarters in the country. This suggests that the headquarters located in the before mentioned cities are larger in size compared to the other headquarters on Canadian territory. The characteristics of the before mentioned nests can be found in Table 1 (Strauss-Kahn \& Vives, 2006). 
Table 1 | Key factors for headquarters relocation

\begin{tabular}{|c|c|c|}
\hline & $\begin{array}{l}\text { Characteristics of areas to which } \\
\text { headquarters are relocated. }\end{array}$ & $\begin{array}{ll}\text { - } & \text { Good airport facilities } \\
\text { - } & \text { Low corporate tax } \\
\text { - } & \text { Low average wages } \\
\text { - } & \text { High levels of business services } \\
\text { - } & \text { Same industry specialization } \\
\text { - } & \text { Agglomeration of headquarters in the } \\
& \text { same sector of activity } \\
\end{array}$ \\
\hline & $\begin{array}{l}\text { Types of companies that relocate their } \\
\text { headquarters more often } \\
\text { (characteristics relative to the others } \\
\text { in the sample) }\end{array}$ & $\begin{array}{ll}\text { - } & \text { Larger (in terms of sales) } \\
\text { - } & \text { Younger } \\
\text { - } & \text { Larger (in terms of number of } \\
\text { headquarters (sic)) } \\
\text { - } & \text { Firms that are foreign } \\
\text { - } & \text { Firms that are the outcome of a } \\
\text { merger }\end{array}$ \\
\hline & $\begin{array}{l}\text { Types of companies that relocate their } \\
\text { headquarters more often } \\
\text { (characteristics relative to the others } \\
\text { in the sample) }\end{array}$ & $\begin{array}{ll}\text { - } & \text { Good airport facilities } \\
\text { - } & \text { Low corporate tax } \\
\text { - } & \text { Agglomeration of headquarters in the } \\
& \text { same sector of activity } \\
\end{array}$ \\
\hline
\end{tabular}

\subsection{Research questions}

From our literature review, it is clear that the much of the existent research has been focused on corporate dominance in the context of North America and research on corporate dominance in Germany and key factors for the relocation of HQs is relatively scarce. Therefore, the purpose of this paper is to identify the centers of corporate dominance in Germany and to evaluate the reasons for corporate headquarter relocations within the Federal Republic of Germany. Therefore, the two main research questions for this paper are as follows:

(Q1) Which are the centers of corporate dominance in Germany and what are their characteristics?

(Q2) Which are the reasons for recent corporate headquarter relocations within Germany?

\section{Methodology}

To answer research questions, quantitative data on the largest German companies was collected using the Amadeus database. Amadeus contains information on around 21 million companies and includes data points such as: basic company information, company financials, financial strength indicators, the name and contact information of directors, the reports and accounts for listed companies, stock prices, former company names, industryrelated information, and much more (Bureau van Dijk, 2018). The four-search metrics used for this paper included: All active companies and companies with unknown situation; 
Region/Country/region in country: Germany; Operating revenue (Turnover) (EUR): Last available year, Upper; quartile, exclusion of companies with no recent financial data.

The data set was mixed, meaning that some variables were numerical while others were categorical. In the R software, some categorical values (such as NACE code and zip code) were recognized as numeric values whereas some numeric data (such as turnover) were recognized as categorical. Therefore, some variables had to be analyzed in Excel using PivotTables. For descriptive statistics, different PivotTable functions in Excel also make operations easier to execute. Furthermore, some of the variables were too heterogeneous to be used in quantitative analysis. Variables such as Global ultimate owner and trade description were interesting for qualitative assessment of individual companies. With these selections, the maximum number of rows that can be exported in Amadeus was 10,000. For the purpose of answering the first research question Q1, the data of the 10,000 largest companies (Top10000) in Germany was used.

For the purpose of answering the second research question, the same database was consulted. Because the second research question deals with corporate headquarter relocation, historical data on the location of each company's HQ was needed. Amadeus did not reveal previous company locations. Therefore, the location from 10 years before the cut-off year (2018) was retrieved from the companies' annual reports. There was no system to conduct this research automatically; it must be done by examining the individual annual reports of each and every company of the database. It is for this reason that the database used for the second research question has to be reduced to the largest 100 companies in the database. This dataset will be called Top100. Out of these 100 companies, some anomalies were identified and therefore eight of them had to be excluded from the database to facilitate the analysis of homogeneous data. There were two reasons for exclusion: (1) Companies with more than one corporate headquarter cannot be considered and (2) companies that were incorporated after 2008 cannot be considered because they had no headquarters in the year 2008.

For the remaining 92 companies, it was possible to identify the headquarter location in 2008. For 85 of those companies, it was possible to retrieve this information from the annual report or the annual report of the parent company. For seven companies, the annual report for the year 2008 was not accessible online because the company either did not publish one in that year or was not obligated to publish an annual report due to its legal status. In those cases, the information was retrieved from the company website (two cases), and in one case each from Bloomberg, the German Bundesanzeiger, the Verband der Vereine Credit form and the Hannoversche Allgemeine Zeitung. 


\section{Results}

\subsection{Frequency distribution of corporate headquarters among German cities}

In accordance with the literature review, centers of corporate dominance in Germany were found to be distributed differently from those in other European countries. The frequency distribution based on the dataset Top10000 gave a good overview of the most dominant cities in terms of their relative and cumulative share of corporate headquarters in the dataset. Table 2 shows the top 13 cities (up to a cumulative relative frequency of 25 per cent15). Overall, the headquarters of the dataset Top 10000 were distributed over 2071 cities. This alone does not allow any conclusions since this number gives no insight in how the headquarters are distributed among these cities. A frequency distribution analysis allowed for more meaningful insights about corporate dominance of German cities. Out of all the cities in the dataset, nine cities host more than one per cent of all corporate headquarters in the dataset and none of the cities host more than five per cent of the corporate headquarters in the dataset. The city with the highest number of corporate headquarters from the dataset was Hamburg, followed by Munich, Berlin, Frankfurt, Cologne and Dusseldorf. Although there was a significant number of headquarters located in the Hamburg (the most dominant city), the number only represented 4.82 per cent of all companies in the dataset. Out of the 13 cities listed in Table 2, seven were the capital of their respective state. Furthermore, these 13 cities were among the 22 largest cities in Germany (measured by size of population). Within the group, Berlin was the most populous city (3.6 million) and Mannheim was the least populous city with population of 308 thousand (citypopulation.de, 2018).

Table 2 | German centers of corporate dominance, top 25\% cumulative relative frequency

\begin{tabular}{|r|l|c|c|c|c|}
\hline $\begin{array}{r}\text { 吕 } \\
\widetilde{\varpi}\end{array}$ & & $\begin{array}{c}\text { Number } \\
\text { of HQs }\end{array}$ & $\begin{array}{c}\text { Relative } \\
\text { frequency }\end{array}$ & $\begin{array}{c}\text { Cumulative } \\
\text { frequency }\end{array}$ & $\begin{array}{c}\text { Cumulative } \\
\text { relative } \\
\text { frequency }\end{array}$ \\
\hline 1 & HAMBURG & 477 & $4.82 \%$ & 477 & $4.82 \%$ \\
\hline 2 & MÜNCHEN & 353 & $3.57 \%$ & 830 & $8.39 \%$ \\
\hline 3 & BERLIN & 336 & $3.40 \%$ & 1166 & $11.79 \%$ \\
\hline 4 & FRANKFURT & 232 & $2.35 \%$ & 1398 & $14.13 \%$ \\
\hline 5 & KÖLN & 229 & $2.32 \%$ & 1627 & $16.45 \%$ \\
\hline 6 & DÜSSELDORF & 221 & $2.23 \%$ & 1848 & $18.68 \%$ \\
\hline 7 & ESSEN & 115 & $1.16 \%$ & 1963 & $19.85 \%$ \\
\hline 8 & STUTTGART & 115 & $1.16 \%$ & 2078 & $21.01 \%$ \\
\hline 9 & BREMEN & 104 & $1.05 \%$ & 2182 & $22.06 \%$ \\
\hline 10 & HANNOVER & 97 & $0.98 \%$ & 2279 & $23.04 \%$ \\
\hline
\end{tabular}




\begin{tabular}{|c|l|l|l|l|l|}
\hline 11 & NÜRNBERG & 89 & $0.90 \%$ & 2368 & $23.94 \%$ \\
\hline 12 & MANNHEIM & 78 & $0.79 \%$ & 2446 & $24.73 \%$ \\
\hline 13 & DUISBURG & 73 & $0.74 \%$ & 2519 & $25.47 \%$ \\
\hline
\end{tabular}

The rather low relative dominance of the top cities in the dataset raised the question of how corporate headquarters were distributed towards the bottom of the list. To answer this question, a frequency distribution analysis was performed. The analysis revealed that the 44.76 per cent of the 2071 cities in the dataset host only one company's corporate headquarters. Moreover approximately 19 per cent host two corporate headquarters and another ten per cent host three corporate headquarters. In addition to this, over 90 per cent of cities in the dataset host eight corporate headquarters or fewer. This point seems to be the most relevant finding in this regard when attempting to identify centers of corporate dominance as 90 per cent of the companies in the dataset host fewer than eight corporate headquarters and can therefore not be considered dominant. On the other hand, based on the information displayed in Table 2, it can be said that 0.6 per cent of cities in the dataset host 25.47 per cent of corporate headquarters. Therefore, it can be assumed that Germany is decentralized as far as corporate power is concerned but that there still exist certain cities where a certain corporate dominance can be observed.

\subsection{Characteristics of German centers of corporate dominance}

One of the variables in the Top 10000 data set was the NACE code. The NACE code is used to classify economic activities within the European Union. While most countries have their own national classification system to classify companies into industries and industry sectors, the NACE code allows a comparison on the European level. The NACE system is integrated into the ISIC standard industrial classification of all economic interviews by the United Nations. The corresponding NACE code being attached to each row of company information in the Top10000 database allows for a comparison of frequency. The frequency distribution of NACE codes in a city or region gives a first understanding of the main industries in the area. For the purpose of keeping the overview easy to understand, only the first three most dominant industries (the NACE codes with the highest frequency) for each center of corporate dominance identified in Table 2 were used.

Starting from a country-wide perspective, Table 3 shows that 14.7 per cent of the 10,000 largest companies were in the business of Activities of head offices i.e. NACE code 7010. This includes overseeing and managing of other units of the company, undertaking the strategic or organizational planning and decision making role, exercising operational control and managing operations of related units (SIC Codes, 2018). This broad definition can include companies from many different industries. Some companies with NACE code 7010 included E.ON, INA-Holding Schaeffler, Deutsche Bahn, RWE AG, Innogy, Fresenius, Edeka, REWE, Media-Saturn Holding and Heraeus Holding etc. 
The second most dominant NACE code in the dataset was 6420 - Activities of holding companies. This includes holding companies that hold assets but do not provide any other services to the businesses in which they hold equity. Some large German companies with the NACE code 6420 were Otto AG fuer Beteiligungen, EMS-Weser-Elbe Versorgungsund Entsorgungsverband, Merck Financial Services, UEE Holding, Saferoad Holding and Rossman Beteiligungs GmbH.

Table 3 | Most dominant industries in centres of corporate dominance

\begin{tabular}{|c|c|c|c|c|c|c|}
\hline \multirow{2}{*}{ City } & \multicolumn{5}{|c|}{ Relative frequency of the three most frequent NACE codes } \\
\cline { 2 - 7 } & 1st & Percentage & 2nd & Percentage & 3rd & Percentage \\
\hline HAMBURG & 7010 & $12.03 \%$ & 6420 & $8.90 \%$ & 5229 & $3.73 \%$ \\
\hline MÜNCHEN & 7010 & $11.86 \%$ & 8299 & $4.80 \%$ & 6420 & $4.80 \%$ \\
\hline BERLIN & 7010 & $13.35 \%$ & 8610 & $5.64 \%$ & 6820 & $4.45 \%$ \\
\hline FRANKFURT & 6420 & $6.84 \%$ & 7010 & $5.98 \%$ & 5229 & $5.13 \%$ \\
\hline KÖLN & 7010 & $17.39 \%$ & 8610 & $3.48 \%$ & 6420 & $3.04 \%$ \\
\hline DÜSSELDORF & 7010 & $15.77 \%$ & 4675 & $4.95 \%$ & 4672 & $4.50 \%$ \\
\hline ESSEN & 7010 & $14.78 \%$ & 6420 & $9.57 \%$ & 8610 & $6.09 \%$ \\
\hline STUTTGART & 7010 & $18.80 \%$ & 5811 & $4.27 \%$ & 8610 & $3.42 \%$ \\
\hline BREMEN & 7010 & $24.04 \%$ & 5229 & $8.65 \%$ & 6420 & $5.77 \%$ \\
\hline HANNOVER & 7010 & $19.39 \%$ & 6820 & $7.14 \%$ & 3511 & $6.12 \%$ \\
\hline NÜRNBERG & 7010 & $20.88 \%$ & 8299 & $5.49 \%$ & 6420 & $5.49 \%$ \\
\hline MANNHEIM & 7010 & $12.66 \%$ & 7490 & $5.06 \%$ & 3511 & $5.06 \%$ \\
\hline DUISBURG & 7010 & $17.81 \%$ & 8610 & $8.22 \%$ & 5229 & $5.48 \%$ \\
\hline GII (Germany) & 7010 & $14.70 \%$ & 6420 & $5.53 \%$ & 8610 & $4.14 \%$ \\
\hline
\end{tabular}

The third most dominant NACE code in the dataset is 8610 - Hospital activities. The class includes all types of short- and long-term hospital activities, services of medical and paramedical staff, medical laboratories, ER services, etc. Some large German companies with the NACE code 8610 include Charite Berlin, Rhoen-Klinikum, Asklepios Kliniken Hamburg and Universitaetsklinkum Schleswig-Holstein. All of these companies are regional hospitals or companies managing a group of hospitals. Because the health care sector is dominated by a few large companies (hospitals are large by their nature), it is not surprising to find that it constitutes a considerable portion of Germany's largest companies.

The three most dominant codes $(7010,6420$ and 8610) in the dataset showed that within the largest 10,000 German companies, 24.37 per cent of them are involved in activities of head offices, holding companies and hospitals. Since the rank order in the list was established by 
turnover, the dominance of these three types of companies was easily explained. It was interesting to see that the most frequent NACE codes in all of Germany were almost proportionally represented in the group of centers of corporate dominance. 22.6 per cent of companies within the dataset were associated with the same three most dominant NACE codes. The difference in the cumulative frequency can be mainly explained by the difference in the importance of hospital activities.

To establish the statistical relevance of the difference between the frequency distribution of the three most dominant NACE codes in the group and all companies in the dataset, the following method was used: A 95 per cent confidence interval was constructed for the proportion in the sample (Group) and compared with the population value (Germany) of the parameter. It must be noted that the percentage values for the group were not the aggregate percentage values of the thirteen cities within the group but the result of a separate calculation based on the original data in the database for these 13 cities all together.

The z-value was calculated in Excel with the =NORMINV() function. The probability was set at 97.5 per cent (for a confidence interval of five per cent), the mean at 0 and the standard deviation at 1 . The value $\hat{\mathrm{p}}$ is the respective value to be tested and the outcome will define the range of values included in the confidence interval. The $\mathrm{z}$-value amounts to 1.959 . The value $n$ (size of the sample) is taken from the original database Top10000.

Table 4 shows that the differences in NACE code dominance between the group of centers of corporate dominance and all cities in the dataset were not statistically significant. However, some observations about the differences of dominance of NACE codes between cities can be made. While the importance of industries in the 13 most important centers of corporate dominance were proportionate to the percentages in the entire dataset, the centers were not homogenous among each other.

Table 4 | Statistical relevance of differences in most dominant industries

\begin{tabular}{|l|r|r|r|}
\hline Industry affiliation (NACE code) & 7010 & 6420 & 8610 \\
\hline Sample proportion & 0.1416 & 0.0556 & 0.0288 \\
\hline Population proportion & 0.1470 & 0.0553 & 0.0414 \\
\hline $\boldsymbol{z}$ & 1.9599 & 1.9599 & 1.9599 \\
\hline $\boldsymbol{n}$ & 359 & 141 & 73 \\
\hline$\hat{\boldsymbol{p}}$ & 0.1416 & 0.0556 & 0.0288 \\
\hline Standard error & 0.0361 & 0.0378 & 0.0384 \\
\hline Upper limit & 0.1777 & 0.0934 & 0.0672 \\
\hline Lower limit & 0.1055 & 0.0178 & -0.0096 \\
\hline Statistical relevance of differences & FALSE & FALSE & FALSE \\
\hline
\end{tabular}


It can be observed that in nine out of 13 corporate centers the importance of head office activities was higher than in the nation as a whole with Bremen at 24 per cent and Nuremberg at almost 21 per cent. An outlier within the group was certainly Frankfurt, the only city where holding company activities were more important than head office activities. Next to the three most important NACE codes in Germany, the thirteen selected cities on the list exhibit different concentrations as well. After taking head office, holding company and hospital activities out of the equation, the differences of each city from the national average should best explain the dominant industries specific to the city.

\subsection{Recent headquarter relocations in Germany}

Based on the Top100 database, the changes in headquarter locations of the 92 companies, 21 in the database were analyzed for the year 2008 and 2018. In addition to cities gaining additional headquarters within the largest 100 companies by attracting newly incorporated companies (after 2008), there has been some movement between cities. Seven of the largest 100 German companies relocated their corporate headquarters to another city. The company names as well as the headquarter locations in both 2008 and 2018 can be seen in Table 5 . The table shows that the relocations of corporate headquarters did not happen exclusively between cities which have relatively high corporate dominance. The companies E.ON and Thyssenkrupp both moved from Dusseldorf (6th in corporate dominance) to Essen (7th). Rewe, Brenntag and Lanxess moved from less to more corporate dominant cities and TenneT TSO was the only company that moved from a city high in corporate dominance to a city with a comparatively low score (from Munich (2nd) to Bayreuth (56th)).

Table 5 | Overview over headquarter relocations in Germany between 2008 and 2018

\begin{tabular}{|l|l|l|}
\hline Company & HQ IN 2008 & HQ IN 2018 \\
\hline E.ON SE (3) & DÜSSELDORF (6) & ESSEN (7) \\
\hline THYSSENKRUPP AG (20) & DÜSSELDORF (6) & ESSEN (7) \\
\hline REWE DEUTSCHER SUPERMARKT AG (29) & WIESBADEN (17) & KÖLN (5) \\
\hline TENNET TSO GMBH (44) & MÜNCHEN (2) & BAYREUTH (56) \\
\hline BRENNTAG AG (72) & MÜLHEIM (42) & ESSEN (7) \\
\hline LANXESS AKTIENGESELLSCHAFT (83) & LEVERKUSEN (59) & KÖLN (5) \\
\hline KION GROUP AG (94) & WIESBADEN (17) & FRANKFURT (4) \\
\hline $\begin{array}{l}\text { Numbers in brackets ( ) show the rank of the } \\
\text { company according to size in 2018 in the } \\
\text { dataset Top100 }\end{array}$ & $\begin{array}{l}\text { Numbers in brackets ( ) show the rank of } \\
\text { corporate dominance }\end{array}$ \\
\hline
\end{tabular}

It should be noted that the table did not include potential losses of Top100 headquarters because they either (1) are not included in the Top100 list but would have been in 2008 or (2) there was a complete shut-down of the company. The reason for this limitation is that the data was not available in the Amadeus database and adding the data through desk research 
would entail comparing databases with structures different from that of the Amadeus database and effort beyond the scope of this paper.

Even though the number of observations were not large enough for statistical analysis, it can be said that Dusseldorf and Wiesbaden were the two cities who have lost the most companies (two each) to Essen, Cologne and Frankfurt. In the studied period, Essen was able to gain four Top100 headquarters without losing a single one and Berlin and Cologne now host two additional Top100 corporate headquarters compared to 2008.

\subsection{The role of trade tax rates in host city attractiveness}

In Germany, corporations were subject to a number of different taxes such as corporate income tax, trade tax, solidarity surcharge etc. Corporate income tax, capital gains tax and the solidarity surcharge were set at a national level and therefore the location within Germany did not have an impact on the company's tax burden for these specific types of taxes. The real estate transfer tax is a one-time tax and therefore should not have a major effect on choosing a location for corporate headquarters either. Therefore, the municipal real estate tax and, first and foremost, the trade tax rate are left for companies to consider as a decision factor when searching for a host city. On the other hand, these tax rates constitute factors in the overall political resources that cities have at their disposal to determine the attractiveness as HQ hosts. The municipal real estate tax differs from federal state to federal state. Within a federal state, the municipalities set similar municipal real estate tax rates to avoid municipality shopping 34 within the federal state. While the differences in municipal estate tax can surely render a location more or less expensive because of its annual collection (Deloitte, 2017), it is less relevant as a decisive factor when companies chose between cities in the same region.

The trade tax rate, on the other hand, can differ greatly from city to city. The calculation method differs between sole proprietorships and partnerships (as one group) and corporations. (IHK, 2018) Because the largest German companies are mainly corporations, the calculation method for corporations was chosen to provide an overview of how the rate is composed. Corporate income under 24,500 Euros are exempt from the tax and there are several additions and deductions before the trade profit can be established. The trade profit is a precisely defined calculated profit used as the basis to which the trade tax rate and the multiplier are applied (Gewerbeanmeldung.de, 2018). The chamber of commerce for trade and industry IHK (2018) provides an overview of the calculation of the trade tax burden (see Equation 2). 
Corporate income (profit)

+ Additions to the calculation base (25\% of interest paid after a lump sum exception of 100,000 Euros)

$=$ Sum

/ Deductions (e.g. 1.2\% of the assessed value of real estate

owned) $=$ Trade profit

x $3.5 \%$ base trade tax rate

$=$ Base trade tax

x Municipal multiplier

$=$ Trade tax burden

The calculation of the trade tax burden is standardized in all of Germany according to the general trade tax obligation. The effect regional tax policy can have on the final trade tax burden on companies residing in the respective city is due to the municipalities' liberty to set the multiplier which is regulated by the municipal tax law. Trade tax law mandated municipalities to set a multiplier of at least 200 per cent but does not set a maximum amount for the multiplier. This can lead to considerable differences in trade tax burdens. The highest multiplier is applied in Didierfeld, the municipality increases the base trade tax by 900 per cent (Gewerbeanmeldung.de, 2018). This serves to show that the multiplier is an impactful tool which can increase the trade tax burden from a minimum of 7 per cent (base trade tax * minimum multiplier) to 31.5 per cent (base trade tax $*$ multiplier of 900 per cent) and theoretically even more.

The trade tax burden is commonly considered as a factor in the attractiveness of municipalities to companies. For municipalities, the possibility of setting the trade tax multiplier contributes to the political resources which can be deployed to render a location more or less attractive. In turn, a reduction of the multiplier also has a direct influence on the municipal budget. Trade tax revenue is the most important source of municipal income (BVMW, 2017). For example, 50.3 per cent of all municipal tax revenue comes from the trade tax. This includes indirect tax revenue from the redistribution of federally collected taxes (Süddeutsche Zeitung, 2017). Nevertheless, the numbers show that many municipalities are happy to adjust the multiplier to generate more revenue or increase their attractiveness as a host for businesses. An illustrative example for successful positioning as a low-trade tax municipality is the municipality of Grünwald bei München: The municipality is home to 11,000 inhabitants and hosts a total of 7,000 companies. The municipality's treasurer attributes this high firm-to-population ratio to the low multiplier of 240 per cent. The total trade tax revenue has not suffered as an effect of the decision; the large number of firms compensates for the forgone revenue due to the low rate (Wiegmann, 2016). 


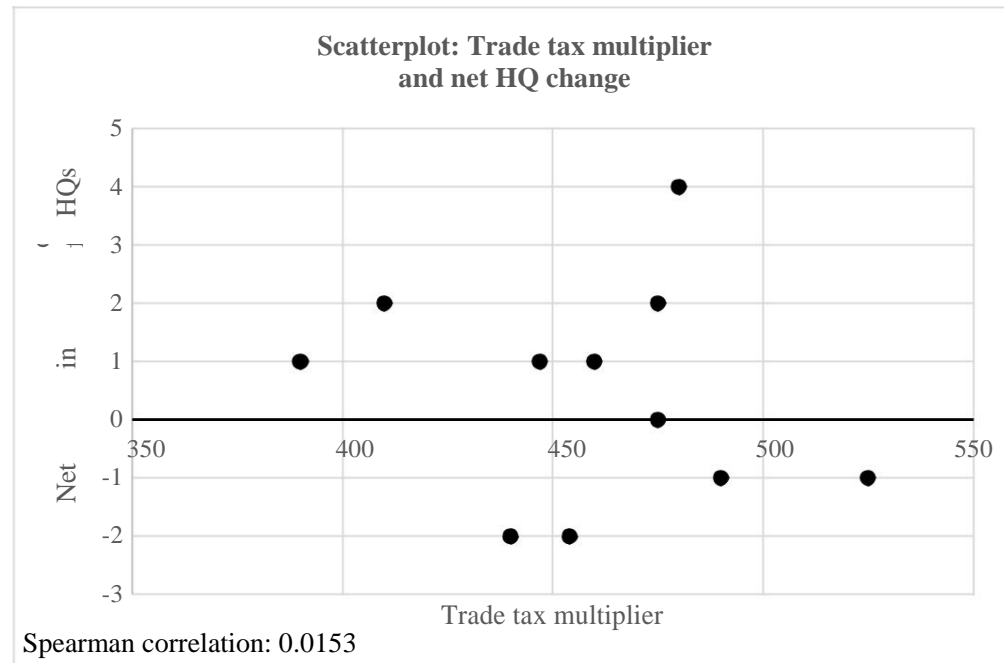

This overview raises the question of whether or not there is a correlation between the current multiplier a municipality has set and the net change in HQs over the last ten years. The scatterplot in Figure 1 reveals that there is no clear correlation though several observations can be made. Low values of $\mathrm{x}$ are connected with positive values of $\mathrm{y}$ while high values of $\mathrm{x}$ are connected with low values of $\mathrm{y}$. This shows that municipalities with higher trade tax multipliers tend to have a negative net change in HQs while municipalities with lower trade tax multipliers experienced a net gain. However, the correlation is far from clear because around the x-value 450 it can be observed that municipalities with trade tax multipliers in this neighborhood could experience net gains and net losses. When testing the correlation between the two variables, the Spearman method was used. The correlation between trade tax multiplier and the net change in number of HQs amounts to 0.0153 . This value suggests that there is no correlation between the two variables.

\section{Discussion and Conclusion}

Based on our analysis we found that Germany is a country of many centers based on the conclusion made by Guertler (2010). Over 90 per cent of German cities that host at least one of the headquarters of the 10,000 largest companies in Germany host eight or fewer HQs. The city with the highest number of corporate headquarters, Hamburg, hosts less than five per cent of all corporate headquarters in the dataset Top10000. Moreover, 13 cities could be identified as centers of corporate centers although none of them could be defined as the clear national center of corporate dominance. While in the United States, 75 per cent of headquarters are located in the largest 20 urban centers (Strauss-Kahn \& Vives, 2006), the situation in Germany was not comparable. The 13 most dominant German cities host just 
over 25 per cent of the 10,000 largest companies' corporate headquarters. The findings of this paper shows that Germany is a country of many centers and corporate power in the country was decentralized.

Furthermore, the centers of corporate dominance in Germany shared certain characteristics that set them apart from other cities in the country. It was found that there was no statistically relevant difference in the importance of certain industries between the group of centers of corporate dominance and the group of all cities in the database. In both, the group of centers and all of Germany the frequencies of NACE codes showed that activities of head offices, activities of holding companies and hospital activities were the most dominant industries. Within the group of centers, certain differences were identified and these findings suggested that most corporate centers have one or two dominant industries that considerably contribute to the local economy. In Hamburg, Bremen, Frankfurt and Duisburg, transportation support activities were among the three most dominant industries. This was due to their geographic location at important trade routes by sea, land and air. In Munich and Nuremberg, business support service activities stand out; the shared services industry was strong in those two cities. Berlin and Hannover host large real estate and renting companies and the importance of this industry was correspondingly large. In Dusseldorf, the wholesale of chemicals, metals and ores industry was a major contributor to the city's economy whereas Stuttgart is German's capital of book publishing. Mannheim's industrial past can still be seen in the importance of electricity production in the city. The difference in the frequencies of standardized legal forms were relevant. German centers of corporate dominance tend to have more public limited companies and fewer private limited companies.

In literature, part of the definition of centers of corporate dominance was often that the companies of which the centers host the HQ were larger in size than in the rest of the respective country (Wheeler, 1988; Clausing, 2010; Rao, 2015) and this holds true in Germany, as well. German corporate centers were more likely to host the corporate headquarters of companies with a turnover of over one billion Euros. They were also less likely to host HQs of companies with a turnover of under 100 million Euros.

The seven recent relocations in Germany were due to merger and demerger activities, expansion and centralization of functions. Due to the low number of observations it was possible that the findings did not proportionally reflect the main drivers for all HQ relocations in Germany. However, it was still interesting to see that the main drivers identified in this paper were in line with findings in literature. All of the five factors identified by Ye et al. (2011) can be found in the recent HQ relocation drivers in Germany. Five of the $12 \mathrm{HQs}$ gained were due to start-ups, one of the relocations was due to expansion, three were due to mergers \& demergers, and two were due the need for a centralization of functions (which could play into the factor of outgrowing the current location).

Strauss-Kahn \& Vives (2006) found that companies tend to relocate to cities with good airport facilities, low corporate tax, low average wages, and high levels of business services, 
same industry specialization and an agglomeration of headquarters in the same sector of activity. Not all of these findings were in line with the findings of this paper. The only clear match was the first factor: Six of the seven companies that relocated now have their headquarters in Essen, Cologne and Frankfurt. All these three cities have excellent airport facilities. These cities did not have low average wages, but the level of business services was high. An interesting specificity of the German market was the issue of tax (the second factor in Strauss-Kahn \& Vives' list): Low corporate tax (or in the case of Germany, trade tax) could not be identified as a relevant decision factor for HQ relocations based on the data used in this paper. No correlation could be found between the trade tax multiplier and the net change in HQ count in the respective cities. This was in line with the findings of Clausing (2010) who did not find evidence that would suggest a strong relationship between tax policy variables and the location of the largest 500 firms in the world.

Furthermore, it could be identified that relocations in Germany mainly happened between cities that were geographically close to each other. Germans dislike long commutes and were not easily ready to relocate their domicile to keep their job at a relocating company. Findings about German commuter behavior (Stutzer \& Frey, 2007; Buehler, 2011) support this conclusion. The findings of the paper in combination with previous findings in literature suggest that the main drivers for relocation were corporate restructuring (M\&A, demergers), expansion and centralization of functions.

\section{References}

Boyle, M. R. (1988). Corporate Headquarters as Economic Development Targets. Economic Development Review, 6(1), 50-56.

Buehler, R. (2011). Determinants of transport mode choice: a comparison of Germany and the USA. Journal of Transport Geography, 19(4), 644-657.

Bureau van Dijk (2018). Amadeus | Overview. Retrieved November 10, 2018 from https://www.bvdinfo.com/en-gb/our-products/data/international/amadeus.

Burress, D. (2006). Attracting and Retaining National Corporate Headquarters in Kansas. Topeka, KS: Ad Astra Institute of Kansas.

BVMW (2017). Steigende Hebesätze - Wo können sich Betriebe günstig ansiedeln?

Retrieved September 20, 2018 from

https://www.mittelstandinbayern.de/steigende-hebesaetze-wo-koennen-sichbetriebe-guenstig-ansiedeln/.

Clausing, K. A. (2010). Should Tax Policy Target Multinational Firm Headquarters? National Tax Journal, 63(4), 741-764.

Collis, D. J., Young, D., \& Goold, M. (2009). International Differences in the Size and Roles of Corporate Headquarters: An Empirical Examination. Harvard Business School Working Paper 10-044.

Deloitte (2017). Taxation and Investment in Germany 2017. Deloitte Touche Tohmatsu Limited. 
Deutsche Börse (2018). Overview Index Changes (from 24 September 2018). Frankfurt: Deutsche Börse.

Gewerbeanmeldung.de (2018). Was ist der Gewerbesteuer-Hebesatz? Retrieved August 29, 2018 from https://www.gewerbeanmeldung.de/gewerbesteuer-hebesatz.

Ye, G., Wan, Q., \& Chen, J. (2011). Political resources, business model and headquarters location of private enterprises. Nankai Business Review International, 2(2), 172194.

Guertler, D. (2010). Wirtschaftsatlas Deutschland. Berlin: Rowohlt Berlin Verlag GmbH. Holloway, S., \& Wheeler, J. (1991). Corporate Headquarters Relocation and Changes in Metropolitan Corporate Dominance, 1980-1987. Economic Geography, 67(1), 5474.

IHK (2018). Berechnung der Gewerbesteuer. Retrieved September 15, 2018 from: https://www.frankfurt-main.ihk.de/recht/steuerrecht/gewerbe_grund/berechnung/. Machek, M. (2012). Retail market structure development in Central Europe. Central European Business Review, 1(3), 22-27.

Porter, M. E. (1996). Competitive advantage, agglomeration economies, and regional policy. International Regional Science Review, 19(1-2), 85-90.

Rao, S. (2015). Mobility and Economic Importance of Corporate Headquarters and Headquarter Functions: A Canadian Perspective. Transnational Corporations Review, 7(2), 128-147.

SIC Codes (2018). SIC Codes information. Retrieved September 2, 2018 from https://www.siccodes.net/classification/class.

Stevens, L., \& Morris, K. (2018). Amazon Picks New York City, Northern Virginia for Its HQ2 Locations. Retrieved October 2, 2018 from

https://www.wsj.com/articles/amazon-chooses-new-york-city-and-northernvirginia-for-additional-headquarters-1542075336.

Strauss-Kahn, V., \& Vives, X. (2006). Why and where do headquarters move? Barcelona: IESE Business School - University of Navarra.

Strickland, D., \& Aiken, M. (1984). Corporate influence and the German urban system: Headquarters location of German industrial corporations, 1950-1982. Economic Geography, 60(1), 38-54.

Stutzer, A., \& Frey, B. S. (1992). Commuting and life satisfaction in Germany.

Informationen zur Raumentwicklung, 2(3), 179-189.

Süddeutsche Zeitung (2017). Gewerbesteuer auf hohem Niveau. Retrieved September 30, 2018 from https://www.sueddeutsche.de/muenchen/erding/landkreis-erdinggewerbesteuer-auf-hohem-niveau-1.3628695.

Wharton (2017). The Headquarters Checklist: How Do Companies Pick a Location?

Retrieved September 23, 2018 from

http://knowledge.wharton.upenn.edu/article/headquarters-checklist-companiespick-location/.

Wheeler, J. O. (1988). The corporate role of large metropolitan areas in the United States. Growth and Change, 19(2), 75-86. 
Wiegmann, D. (2016). Reichtum als Standortvorteil. Retrieved September 10, 2018 from https://www.suedkurier.de/ueberregional/baden-wuerttemberg/Reichtum-alsStandortvorteil;art417930,8542224.

\section{Authors}

\section{Ladislav Tyll}

Department of Strategy

Faculty of Business Administration

University of Economics, Prague

Nám. W. Churchilla 4, 13067 Prague 3, Czech Republic

ladislav.tyll@vse.cz

\section{Mohit Srivastava}

Department of Strategy

Faculty of Business Administration

University of Economics, Prague

Nám. W. Churchilla 4, 13067 Prague 3, Czech Republic mohit.srivastava@vse.cz

\section{Florián Brezina}

Department of Strategy

Faculty of Business Administration

University of Economics, Prague

Nám. W. Churchilla 4, 13067 Prague 3, Czech Republic

bref00@vse.cz 